藤永 卓司, 池田 政樹, 村田 祥武

\begin{abstract}
要旨
左主気管支入口部に発生した粘表皮癌に対して大動脈脱転を行い，気管支切除および吻合を行った症例を経験したので報 告する. 症例は 22 歳男性, 血痰があり当院紹介となった. 胸部造影 CT 検査にて左主気管支入口部を閉塞する血流豊富な腫 瘤を認め，壁外浸潤の可能性が示唆された。気管支鏡検査では膜様部に基部のある腫瘍は易出血性であった。手術では大動 脈の前方への挛引を行い，左主気管支と気管分岐部を十分に露出した，良好な視野で腫瘍を含めて左主気管支を楔状に切除 し，吻合を行った.
\end{abstract}

索引用語 : 大動脈弓, 脱転, 主気管支, 粘表皮癌, 気管支形成術 aortic arch, retraction, main bronchus, mucoepidermoid carcinoma, bronchoplasty

\section{はじめに}

気管分岐部近傍の左主気管支病変への到達法として は, 前方からの経縦隔経路と側方からの経胸腔経路が考 えられる. 経縦隔経路では左主気管支が大動脈弓の背側 に位置するため, 手術操作が困難な場合がある。経胸腔 経路においても左は大動脈弓があるため工夫が必要であ る. 今回, 大動脈弓下で十分な術野が確保できず, 大動 脈脱転により良好な視野が得られた症例を経験したので 報告する．

\section{症例}

症 例 : 22 歳, 男性.

主 訴：血痰.

現病歴：症状不安定な精神疾患 (アスペルガー症候群) のため専門病院の入退院を繰り返していた. $201 X$ 年 7 月に血痰があり近医受診し, 精査目的で当院紹介となっ た。

国立病院機構長良医療センター呼吸器外科

原稿受付 2016年 6 月17日

原稿採択 2016年 8 月19日

本論文の要旨は第 33 回日本呼吸器外科学会総会 (2016 年 5 月，京都市）で発表した。
既往歴：14 歳 統合失調症, アスペルガー症候群.

喫煙歴：なし

家族歴：特記すべきことなし.

入院時現症 : 身長 $167.7 \mathrm{~cm}$ 体重 $48.4 \mathrm{~kg}$, 体温 $36.4^{\circ} \mathrm{C}$, 脈拍 95 回/分・整, 左側で呼吸音の減弱あり.

血液検査所見：CEA $2.4 \mathrm{ng} / \mathrm{mL}$, CYFRA $0.9 \mathrm{ng} / \mathrm{mL}$, SCC $1.4 \mathrm{ng} / \mathrm{mL}$ ，ProGRP 70.3 pg/mL，NSE $33.7 \mathrm{ng} / \mathrm{mL}$ と ProGRP と NSEの軽度上昇を認めた。他特記すべき 異常なし.

動脈血ガス分析：室内気下で pH 7.391, PCO2 42.5 mmHg, PO2 $61.8 \mathrm{mmHg}, \mathrm{HCO} 3-25.2 \mathrm{mmol} / \mathrm{L}$ と低酸素 血症を認めた。

呼吸機能検査：患者の協力が得られず，未実施.

胸部 X 線写真：明らかな異常を認めず.

胸部造影 CT：左主気管支入口部に造影される $1.5 \mathrm{~cm}$ 大の腫瘤を認め (Fig. 1A), 気管支動脈からの栄養血管が 発達していた (Fig. 1B)。 また膜様部壁外に浸潤している 可能性も考えられた (Fig. 1C). 左肺に無気肺, 吸い込み 肺炎像などは認めなかった。

気管支鏡検査（Fig. 2）：腫瘍が左主気管支を閉塞して いたが，気管分岐部側に明らかな浸潤はなく，前壁側で 気管支鏡が通過し，末梢側気管支を観察できた。組織生 検では壊死組織のみで確定診断には至らなかった。腫瘍 


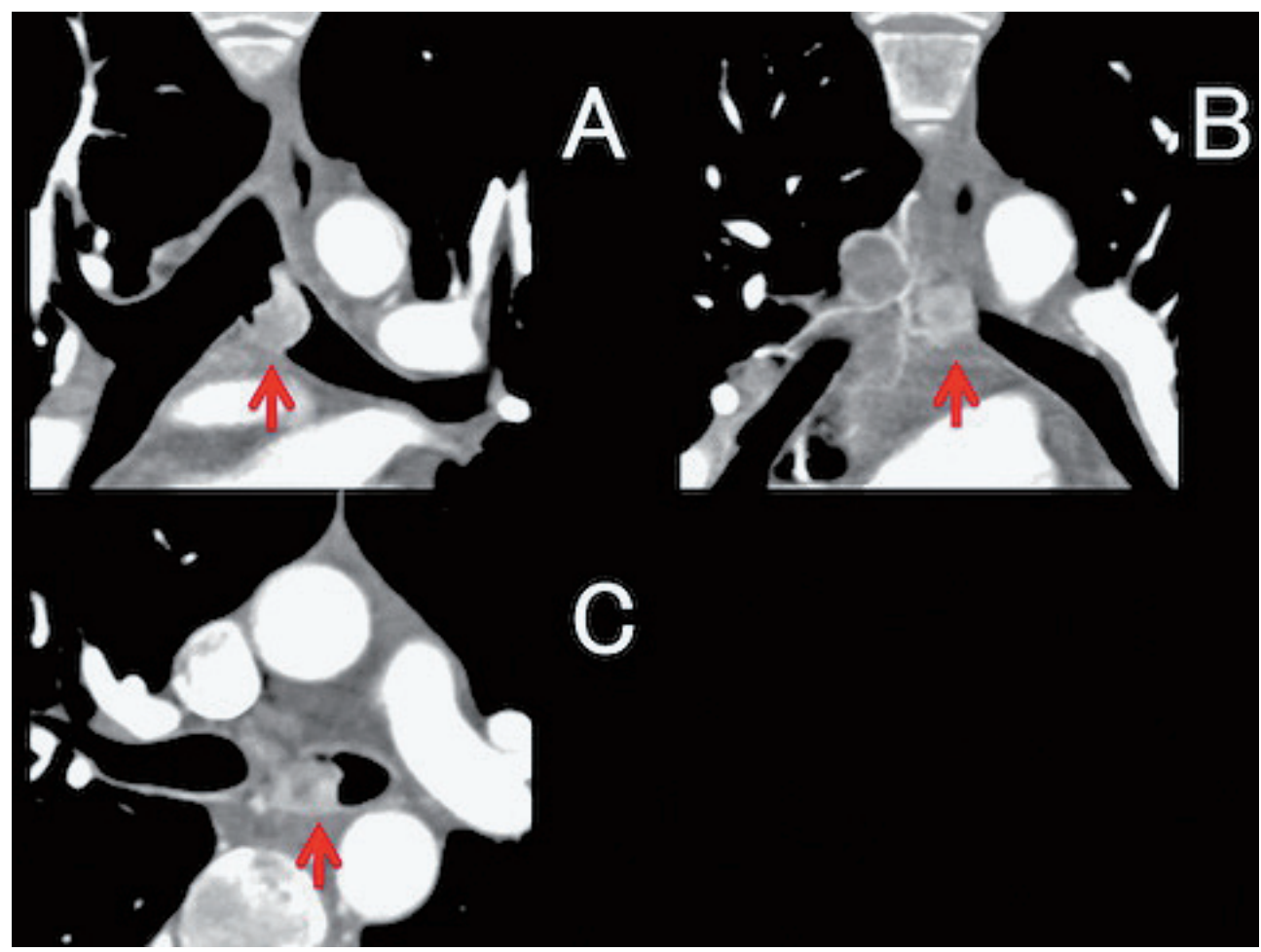

Fig. 1 A) The tumor obstructing the orifice of the left main bronchus. B) The tumor was vascular-rich. C) Extra-bronchial invasion was suggested.

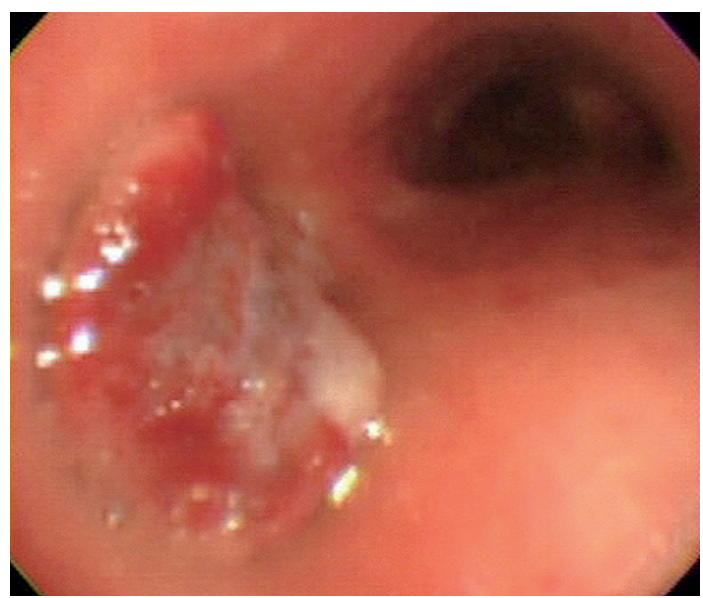

Fig. 2 The tumor obstructing the left main bronchus bled easily. No invasion to the tracheal carina was found.

は易出血性であったため, 繰り返し検体は採取されな かった.

FDG-PET : 腫瘍に軽度集積を認めた (SUVmax 3.28）。転移を疑う所見はなかった。

呼吸器内科で気管支鏡下スネア燒灼による切除も検討
されたが，胸部造影 CT で気管支動脈から比較的太い栄 養血管が侵入していることと気管支壁外への浸潤が疑わ れたことから手術目的で呼吸器外科紹介となった.

鑑別診断として粘表皮癌, 神経内分泌腫瘍, 血管腫, 血管平滑筋腫，炎症性偽腫瘍などが考えられた。基部が 膜様部で壁外浸潤の可能性があったことから, 左開胸了 プローチを選択した。また周術期に精神疾患のため患者 の協力が期待できないと考え，もし分岐部に顕微鏡的浸 潤があっても侵襲の大きい分岐部切除は行わない, 術後 放射線照射追加に備えて有茎肋間筋弁を準備する方針と した.

手術所見：分離換気用チューブは右用を挿入した。後 側方切開, 第 5 肋間開胸で有茎性肋間筋弁を作成した。 ボタロー勒帯を切離, 左主肺動脈を前方に拣引後, 左主 気管支をテーピングし，気管分岐部前面の剥離を行った が，大動脈弓下にて十分な操作スペースが確保できず, 気管のテーピングは困難であったため, 大動脈脱転を行 うことにした. 下行大動脈背側で第 3，4肋間動脈を結紮 切離し, 下行大動脈を前方に搴引すると左主肺動脈, 左 主気管支，気管分岐部，食道が確認できた（Fig. 3, Fig. 
$4 \mathrm{~A})$. 腫瘍末梢側の膜様部側から切開を開始し, 左主気管 支を楔状に切除した (Fig. 4B)。迅速病理診断で切除断端 に腫瘍の遺残がないことを確認した，腫瘍本体の迅速病 理診断は行わなかった。軟骨側は深部を 4-0 PDSII で連

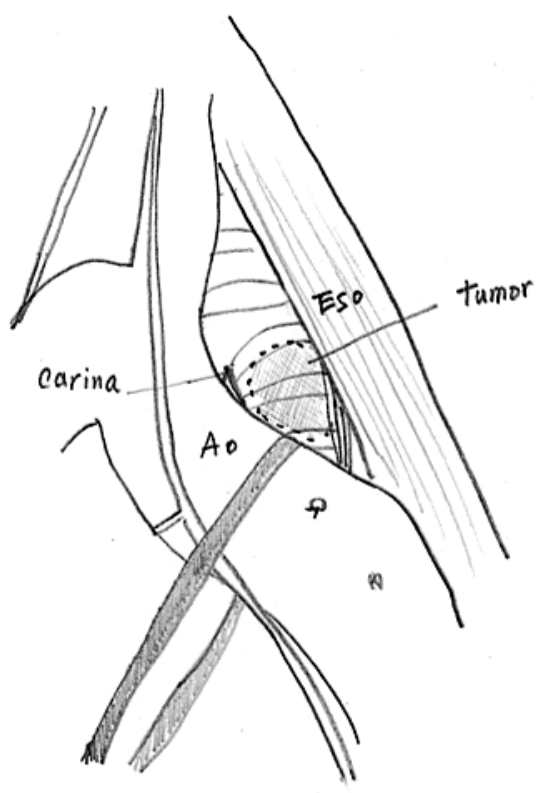

Fig. 3 Ao: descending aorta, Eso: esophagus. Anterior retraction of the aortic arch enabled the left main bronchus with the endobronchial tumor and tracheal carina to be exposed.
続縫合，手前を単結紮で縫合した，続いて膜様部を連続 縫合した。最後に有茎肋間筋弁を吻合部に縫着した。

術後病理診断：腺系分化と扁平上皮系分化を示夺腫瘍 で Ki-67 陽性率は 5-10\% と低く, 異型性, 細胞増殖性の低 い低悪性度粘表皮癌と診断された。切除断端への浸潤は 認めず, リンパ節（＃7，10）にも転移を認めなかった (pT3N0M0).

術後気管支鏡検査（術後 6 力月）：気管支狭窄や腫瘍の 再発は認めなかった（Fig. 5).

\section{考察}

左開胸で分岐部近傍の左主気管支に到達する場合，大 動脈弓の存在が問題になる。前田らは大動脈弓下からで も右主気管支，気管の授動を行い，気管を率引すること で手術操作が容易になると報告した ${ }^{1,2)}$ 。一方，大動脈脱 転での左主気管支への到達法は 1955 年に Björk が報告 しだ． 本症例は，まず左主肺動脈を前方に牽引儿，気管 分岐部前面の鈍的剥離を加えたが，大動脈下で気管テー ピングは困難であった．患者の胸郭が扁平で前後への術 野展開が困難であったことと右用分離換気チューブを挿 入していたことが原因と考えられた，柔軟性のあるシン グルルーメンチューブであればテーピングが容易であっ たかもしれないが，術中腫瘍から出血した時を想定して 分離換気用チューブを選択した。当初気管支外への進展 が危惧されたが, 大動脈の脱転により気管, 気管分岐部,

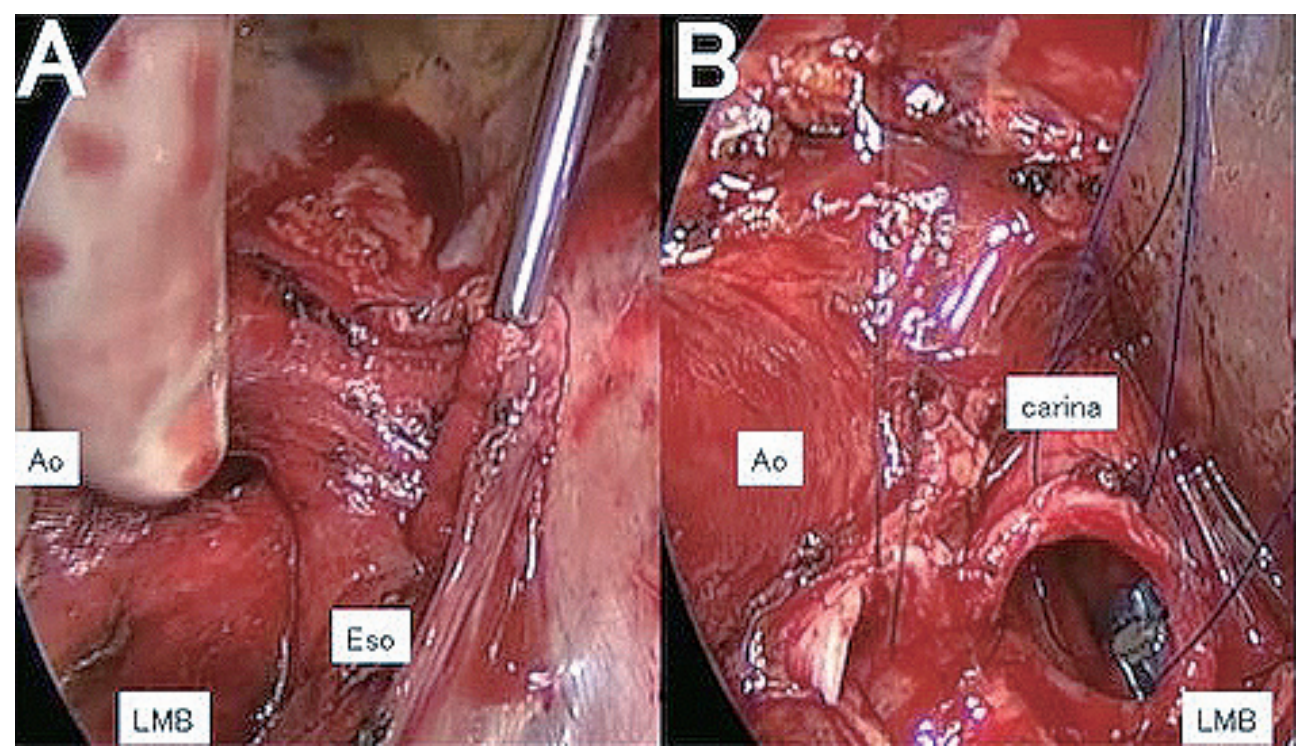

Fig. 4 A) Ao: descending aorta, LMB: left main bronchus, Eso: esophagus. B) Deep wedge resection of LMB was performed. The cartilage of the tracheal carina was preserved. 


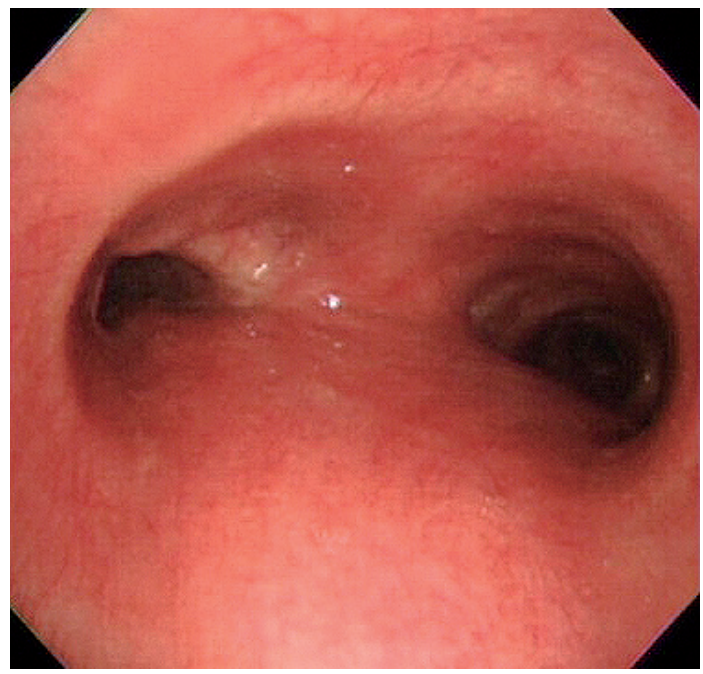

Fig. 5 No stenosis or tumor recurrence was observed 6 months after the operation.

左主気管支の膜様部，食道を背側から良好な視野で確認 でき，食道浸潤にも対応可能と思われた。ただ大動脈の 毫引については動脈硬化を伴うことが多い高齢者では特 に牽引時, 愛護的に扱わなければならない. また肋間動 脈切断に際しては前脊椎動脈症候群が問題になる.アダ ムキュービッツ動脈は左側が 78\%, 第 8～12 肋間動脈レ ベルが $90 \%$ と報告されている ${ }^{4}$. したがって本術式で前 脊椎動脈症候群を発症する可能性は低いが, 下位肋間動 脈を損傷しないように注意が必要である.

今回，右開胸での到達法も術前に検討した，右からの 場合, 容易に両側主気管支, 気管分岐部を露出可能であ るが, Grillo は右開胸での左主気管支病変切除について 術中気道管理が煩雑になる点を指摘している ${ }^{5}$. 今回, 我々は呼吸管理の問題と術後放射線治療の可能性に備え 肋間筋弁を準備することにしていたため右開胸は選択し なかった。

粘表皮癌は肺癌の $0.1 \sim 0.2 \%$ と稀な腫瘍で比較的若年 者の中枢気道にポリープ状に発生することが多い ${ }^{6}$. 細胞 の分化度から低悪性度と高悪性度に分けられるが，低悪
性粘表皮癌のリンパ節転移は稀であり，一般的に完全切 除ができれば予後良好とされる。本症例は低悪性度でリ ンパ節転移もなく完全切除できたが，引き続き慎重に経 過観察を行う予定である。

\section{結語}

左主気管支入口部に発生した粘表皮癌に対して, 大動 脈脱転を行い，左主気管支楔状切除を行った，大動脈脱 転により良好な視野と操作スペースが確保でき，有用で あった

\section{利 益相反}

本論文について申告する利益相反はない.

\section{文献}

1. 前田昌純. 気管 ·気管支形成術. 胸部外科 $1987 ;$ 40: 110520.

2. Maeda M, Nakamoto K, Tsubota N, Okada T, Katsura H. Operative approaches for left-sided carinoplasty. Ann Thorac Surg 1993; 56: 441-6.

3. Björk VO. Left-sided bronchotracheal anastomosis. J Thorac Surg 1955; 30: 492-8.

4. Tanaka H, Ogino H, Minatoya K, Matsui Y, Higami T, Okabayashi $\mathrm{H}$, et al. The impact of preoperative identification of the Adamkiewicz artery on descending and thoracoabdominal aortic repair. J Thorac Cardiovasc Surg 2016; 151: 122-8.

5. Grillo HC. Carinal reconstruction. In: Grillo HC, editor. Surgery of the trachea and bronchi. 1st ed. Hamilton: BC Decker; 2003: 610.

6. 鈴木一彦, 森 裕二, 中田尚志, 大西哲郎, 阿倍庄作. 気 管支管状切除・端々吻合術を施行した中間気管支幹原発 粘表皮癌の 1 例一本邦報告 104 例の臨床像に関する文献 的考察一. 肺癌 2000; 40: 121-7. 


\title{
Resection of mucoepidermoid carcinoma of the left main bronchus by retraction of the aortic arch
}

\author{
Takuji Fujinaga, Masaki Ikeda, Yoshitake Murata \\ Department of General Thoracic Surgery, National Hospital Organization Nagara Medical Center
}

We report a case of left main bronchial mucoepidermoid carcinoma resected by anterior retraction of the aortic arch. The patient was a 22-year-old male who had spontaneous hemoptysis; he was referred to our hospital for further investigation. Enhanced chest computed tomography revealed a vascular-rich endobronchial tumor obstructing the orifice of the left main bronchus, which may have partially invaded the surrounding tissue. Bronchoscopy revealed that the tumor arising from the membrane portion easily bled. During the operation, anterior retraction of the aortic arch after the dissection of the two intercostal arteries provided adequate exposure of the proximal part of the left main bronchus and tracheal carina. The left main bronchus with the lesion was resected by deep wedge fashion; it was anastomosed with a good operative view.

(C) The Japanese Association for Chest Surgery (JACS) 